\title{
Pulmonary manifestations of sickle cell disease
}

\author{
A K Siddiqui, S Ahmed
}

Postgrad Med J 2003;79:384-390

Pulmonary complications account for significant morbidity and mortality in patients with sickle cell disease. Clinical lung involvement manifests in two major forms: the acute chest syndrome and sickle cell chronic lung disease. Acute chest syndrome is characterised by fever, chest pain, and appearance of a new infiltrate on chest radiograph. Sickle cell chronic lung disease, on the other hand, manifests as radiographic interstitial abnormalities, impaired pulmonary function, and, in its most severe form, by the evidence of pulmonary hypertension. Progress has been made in understanding the pathophysiology and management of these complications. In this review the current knowledge of the mechanism, diagnosis, and treatment of pulmonary complications of sickle cell disease are discussed.

See end of article for authors' affiliations

Correspondence to:

Dr Shahid Ahmed, Division

of Hematology-Oncology,

Department of Medicine,

Long Island Jewish Medical

Center, 270-05, 76th Ave,

New Hyde Park, NY,

1 1040, USA;

shahidahmed00@yahoo.com

Submitted 20 September

2002

Accepted 22 March 2003
S ickle cell disease (SCD) is one of the most prevalent genetic disorders. ${ }^{1-3}$ There are more than 200 million carriers of sickle cell trait worldwide, and 200000 to 300000 people are born annually with major haemoglobinopathies. ${ }^{4}$ Approximately $0.14 \%$ of African Americans children are homozygous for the sickle cell gene and $8 \%$ have sickle cell trait, making SCD the most prevalent inherited disorder in African Americans. ${ }^{1-5}$ The protean manifestations of SCD are caused by substitution of glutamic acid by valine in the beta subunits of the haemoglobin molecule. ${ }^{1}$ Upon exposure to low oxygen tension the mutant haemoglobin $\mathrm{S}$ becomes less soluble and aggregates into large polymers. This results in a distorted erythrocyte with marked decrease in its deformability contributing to the vasoocclusive and haemolytic aspects of the disease.

With improved supportive care the median age of survival has risen to 42 years for men and 48 years for women. ${ }^{6}$ As survival into adulthood has become more common in patients with SCD, there has been an increased incidence of chronic organ failure. ${ }^{67}$ The lung is among the major

Box 1: Pulmonary manifestations of sickle cell disease

- Increased airway reactivity.

- Nocturnal oxyhaemoglobin desaturation.

- Thromboembolisms.

- Acute chest syndrome.

- SCCLD: radiographic interstitial lung abnormalities; pulmonary function test abnormalities; pulmonary hypertension. organs involved in SCD. ${ }^{8-10}$ The pulmonary manifestations of SCD are both acute and chronic (see box 1). They remain the leading cause of morbidity and mortality in patients with SCD. Clinical lung involvement commonly takes two major forms: the acute chest syndrome (ACS) and sickle cell chronic lung disease (SCCLD). ${ }^{8-10}$ More than $20 \%$ of adults with SCD have fatal pulmonary complications. ${ }^{6}$ Although pulmonary manifestations of SCD are common, they remain underdiagnosed by physicians. This review summarises the current knowledge and management of pulmonary manifestations associated with SCD.

\section{AIRWAY HYPER-REACTIVITY}

Airway hyper-reactivity is a common pulmonary function test abnormality among young subjects with SCD. ${ }^{11-13}$ The reported incidence of obstructive lung defects in children with SCD is $35 \%$ to $37 \% .{ }^{112}$ A prospective controlled trial demonstrated airway reactivity to cold air in $60 \%$ patients with SCD compared with none in the control population, suggesting an association between SCD and airway reactivity. ${ }^{13}$ The pathogenesis of increased airways reactivity and its relationship to ACS and SCCLD, however, is unknown. In the absence of data on long term benefit, routine use of bronchodilators is not recommended in patients with SCD.

\section{NOCTURNAL OXYHAEMOGLOBIN DESATURATION}

Nocturnal oxyhaemoglobin desaturation has been reported in SCD subjects, with a prevalence of up to $40 \%$ in children and adolescents. ${ }^{14}{ }^{15}$ Proposed mechanisms are obstructive sleep apnoea, intrinsic lung disease, and an abnormality in oxyhaemoglobin affinity. ${ }^{16}$ Several investigators documented obstructive sleep apnoea in SCD with or without nocturnal oxyhaemoglobin desaturation. ${ }^{17-19}$ Although it has been shown that low nocturnal oxygen saturation is associated with higher rate of painful crisis in childhood, the relationship between nocturnal oxyhaemoglobin desaturation and vaso-occlusive crisis or ACS is poorly understood..$^{20}$

\section{THROMBOEMBOLISM}

Patients with SCD are known to be hypercoagulable. ${ }^{2122}$ A variety of mechanisms are postulated from low levels of protein $\mathrm{S}$ and $\mathrm{C}$,

Abbreviations: ACS, acute chest syndrome; MACSS multicentre acute chest syndrome study; $N O$, nitric oxide; NYHA, New York Heart Association; SCCLD, sickle cell chronic lung disease; SCD, sickle cell disease; VCAM-1, vascular cell adhesion molecule- 1 


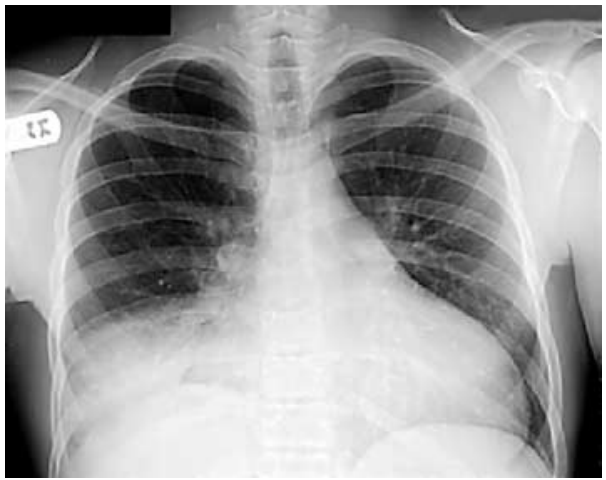

Figure 1 Chest radiograph of a 34 year old man admitted with ACS showing infiltration of right lower and middle lobes. Patient improved after receiving antibiotic therapy and blood transfusion.

\section{Box 2: Risk factors associated with acute chest}

\section{syndrome}

- Younger age

- Homozygous haemoglobin SS.

- Low haemoglobin F concentration.

- High steady state leucocyte counts.

- High haemoglobin levels.

- Previous history of acute chest syndrome.

- Avascular necrosis of bone.

to raised levels of tissue factor and factor VIII, and to enhanced platelet reactivity, as well as to generation of hydroxyl radicals and liberation of fibronectin and thrombospondin. ${ }^{23-27}$ Pulmonary thromboembolism may contribute to both ACS and SCCLD. ${ }^{22} 28$ Although thromembolism has been noted in $8 \%$ to $25 \%$ of necropsy studies in patients with SCD, the exact incidence and prevalence is unknown. ${ }^{79}$

\section{ACUTE CHEST SYNDROME}

\section{Incidence and risk factors}

ACS is defined as the appearance of a new pulmonary infiltrate on chest radiograph (fig 1), accompanied by fever and a combination of respiratory symptoms that include cough, tachypnoea, and chest pain. ${ }^{29-33}$ It is the second most common cause of hospitalisation in patients with SCD and responsible for up to $25 \%$ of deaths. ${ }^{67}{ }^{32}$ ACS has been reported to occur in $15 \%$ to $43 \%$ of patients with SCD. Moreover, recurrent episodes occur in up to $80 \%$ of those who have had a prior episode. ${ }^{32}{ }^{34}$ The incidence is age dependent with rates of 24.5 events per 100 patient years in young children with haemoglobin SS and decreasing to approximately 8.8 events per 100 patient years in older subjects. ${ }^{32}$ ACS rates vary directly with steady state leucocyte counts, haemoglobin concentration, and, inversely, with age and haemoglobin $\mathrm{F}$ levels. ${ }^{32}$ There is also a strong correlation between ACS and the occurrence of neurological complications. ${ }^{31-33}$

\section{Aetiology}

The usual aetiology of ACS is vaso-occlusion, infection, or both simultaneously. Clinically it is impossible to distinguish infection from other causes of ACS. The landmark multicentre acute chest syndrome study (MACSS) reported findings from 671 episodes of ACS in 537 patients with SCD using rigorous methodologies including bronchoscopy, deep sputum cultures, and serological evaluation with polymerase chain reaction to detect Chlamydia pneumoniae. ${ }^{33}$ In this study a specific cause of ACS was identified in 38\% of all episodes and $70 \%$ of episodes with complete data (see table 1). Important causes of acute chest syndrome are described below.

\begin{tabular}{ll}
\hline $\begin{array}{l}\text { Table } 1 \\
\text { syndrome reported in MACSS }\end{array}$ \\
\hline \multicolumn{1}{|c|}{$\begin{array}{c}\text { Causes of acute chest } \\
\text { Causes } \\
\text { episodes } \\
n=670(\%)\end{array}$} \\
\hline $\begin{array}{ll}\text { Fat embolism, with or without } \\
\text { infection }\end{array}$ & $59(8.8)$ \\
Chlamydia & $48(7.2)$ \\
Mycoplasma & $44(6.6)$ \\
Virus & $43(6.4)$ \\
Bacteria & $30(4.5)$ \\
Mixed infection & $25(3.7)$ \\
Legionella & $4(0.6)$ \\
Miscellaneous infections & $3(0.4)$ \\
Infarction & $108(16.1)$ \\
Unknown & $306(45.7)$ \\
\hline
\end{tabular}

\section{Infection}

Patients with SCD are at an increased risk of infection due to abnormalities in host defences including impairment of the complement system and functional asplenia. ${ }^{12}$ In the MACSS study, infection was documented in $30 \%$ of cases with ACS, and 27 different pathogens were identified. Chlamydia pneumoniae was the most frequent pathogen followed by Mycoplasma pneumoniae and respiratory syncytial virus. ${ }^{33}$

\section{Pulmonary fat embolism}

The occurrence of pulmonary emboli containing fat and necrotic bone marrow in patients with SCD is well known. ${ }^{35-37}$ Fat embolism associated ACS was identified in 9\% cases of ACS in the MACSS report..$^{33}$ The pulmonary signs and symptoms typically are preceded by bone pain, with laboratory evidence of a significant decrease in haemoglobin and platelet count and an increased plasma level of free fatty acids and phospholipase A2. ${ }^{38}{ }^{39}$ The diagnosis of pulmonary fat embolism is supported by the presence of lipid-laden macrophages in the bronchoalveolar lavage fluid. The Corwin index is used to quantify the amount of lipid in the pulmonary macrophages..$^{35}$ ACS due to pulmonary fat embolus is associated with severe haematological and clinical abnormalities and has a fourfold higher mortality rate in adults compared to children. ${ }^{32}$

\section{In situ thrombosis}

Pulmonary infarction secondary to in situ thrombosis is a potential cause of ACS, though is uncommonly documented pathologically. ${ }^{22} 40$

\section{Hypoventilation from pain and/or narcotic analgesics}

There is a high correlation between thoracic bone infarction on bone scan and the presence of pulmonary infiltrates. ${ }^{41}$ It has been suggested that bone pain can cause splinting and atelectasis and can present as ACS. ${ }^{42-44}$ Similarly, postoperative thoracic and upper abdominal pain may predispose to ACS. Incentive spirometry and adequate pain control therefore becomes necessary under such situations. ${ }^{44}$ On the other hand, excessive use of narcotics may lead to hypoventilation and ACS as a complication of their use. ${ }^{42}$

\section{latrogenic pulmonary oedema}

Although it has been suggested that aggressive hydration may lead to ACS in patients with SCD, this association is not established. ${ }^{45} 46$

\section{Pathogenesis}

The mechanism responsible for ACS is not fully understood. It is believed to be a specific form of acute lung injury that can progress to acute respiratory distress syndrome. ${ }^{22}{ }^{28}$ The lung 
injury is caused by various insults superimposed on the genetically based pathophysiology of SCD. In addition to haemoglobin S polymerisation and red cell sickling, ${ }^{12}$ increased expression of adhesion molecules on sickle erythrocytes and endothelium, ${ }^{47-49}$ release of inflammatory mediators, ${ }^{38}{ }^{49}$ interaction of sickle red cell with leucocytes, ${ }^{50}{ }^{51}$ microvascular thrombosis, ${ }^{20}$ and endothelial damage may all contribute to microvasculature occlusion and tissue infarction..$^{52} 53$

More recent data suggest that abnormalities in endothelial cell nitric oxide (NO) production and metabolism as well as oxidant status may contribute to the development of ACS. ${ }^{28} 5455$ NO regulates vascular tone and endothelial function, and maintains tissue oxygenation by reducing shun physiology. ${ }^{286}$ Hypoxia induces cytokine and endothelin-1 release which up-regulates expression of the endothelial adhesion receptor vascular cell adhesion molecule-1 (VCAM$1)$, thereby enhancing adhesion of red cells to endothelial cells. Additionally, fat embolism and release of free fatty acids also enhances the adhesion process by VCAM-1 upregulation. ${ }^{57}$ Under normal conditions NO inhibits both endothelin-1 production and endothelial VCAM-1 expression. During ACS, however, hypoxia and red cell sickling inhibit NO production while free radical species released by leucocytes inactivate locally produced NO. Hence, depletion of NO results in unopposed VCAM-1 up-regulation and increased red cell endothelial adhesion. ${ }^{49} 5758$

\section{Clinical features}

The Cooperative Study of Sickle Cell Disease, which prospectively followed up 3751 patients, reported data on 1722 ACS episodes in 939 patients. ${ }^{31}$ Patients with ACS presented with fever $(80 \%)$, cough $(74 \%)$, chest pain $(57 \%)$, dyspnoea $(28 \%)$, productive cough $(24 \%)$, wheezing $(11 \%)$, and haemoptysis $(2 \%)$ accompanied by hypoxia, leucocytosis, and infiltrates on chest radiographs that often progressed to multilobar pulmonary disease indistinguishable from acute respiratory distress syndrome.

The symptoms of ACS are age dependent; ACS is often preceded by febrile episodes in children and by vaso-occlusive crisis in adults. Children are more likely to have fever and cough, whereas adults more commonly experience chest pain and dyspnoea. ${ }^{31-33}$

\section{Management of acute chest syndrome \\ General measures}

SCD patients admitted for painful crisis should be considered in the prodromal phase of ACS. Prophylactic manoeuvres like close pulmonary monitoring, cautious hydration, optimal pain control, and incentive spirometry remain essential components of therapy. Physicians should have a low threshold for ordering a chest radiograph and arterial blood gas analysis.

Vigorous hydration may result in pulmonary oedema and worsening respiratory distress and should be avoided. ${ }^{57}$ Judicious use of analgesics is necessary to relieve bone pain and splinting to prevent lung atelectesis. If there is no contraindication, non-steroidal agents should be the part of all pain control regimens as they have a narcotic-sparing effect. ${ }^{59}$ Efficacy of incentive spirometry in preventing the pulmonary complications (atelectasis and infiltrates) associated with the ACS has been proven in a randomised controlled trial and should be routinely used in patients with SCD. ${ }^{44}$

\section{Oxygen therapy}

Oxygen should be administered for the correction of hypoxia, which if untreated creates a risk of multiorgan failure. ${ }^{57}$ Pulse oximeter correlation with arterial oxygen tension in patients with SCD may at times be poor and arterial blood gas confirmation is required in hypoxic patients..$^{60-62}$
Box 3: Diagnostic testing and laboratory monitoring in acute chest syndrome

- Blood and sputum/tracheal secretion culture.

- Daily blood counts and appropriate metabolic profile.

- Serial measurement of arterial blood gases as necessary.

- Chest radiographs.

- Flexible bronchoscopy with bronchoalveolar lavage as appropriate.

\section{Antibiotics}

Broad spectrum antibiotics, including a macrolide or quinolone in view of atypical infections such as chlamydia and mycoplasma, should be administered. ${ }^{8}$ Penicillin prophylaxis and use of Haemophilus influenzae vaccine has reduced bacterial infection significantly and should be given to all patients with SCD.

\section{Bronchodilators}

Bronchodilators are given to patients when airflow obstruction is present, though some investigators recommend their routine use in all patients. ${ }^{33}$ Many patients with SCD have airway hyper-reactivity and this fact should be considered when managing these patients on the ventilator to prevent autopositive end expiratory pressure and dynamic hyperinflation. $^{33} 34$

\section{Bronchoscopy}

Bronchoscopy may be considered in patients not responding to initial therapy. It can be utilised both as an airway clearance technique by removing the thick and tenacious airway secretions often found in patients with ACS and for more accurate diagnosis of the episode. ${ }^{8363}$

\section{Transfusion}

Simple and exchange blood transfusion may be beneficial by lowering the fraction of sickle haemoglobin and also by improving the oxygen carrying capacity of blood. Both simple and exchange transfusion have resulted in similar improvement in oxygenation in patients with ACS. ${ }^{33}{ }^{57}{ }^{64}$ Transfusion is indicated in individuals with severe disease, multilobe involvement, persistent or worsening hypoxaemia, neurological abnormalities, multiorgan failure, or those with a history of cardiac disease. ${ }^{131-33}$ In patients with severe anaemia, simple transfusion appears to be the modality of choice. However, a post-transfusion increment in haemoglobin levels above 110 g/l may be dangerous due to increased blood viscosity and therefore in individuals with a relatively high haemoglobin exchange transfusion should be performed. ${ }^{65}$ Severe episodes may not respond to transfusion therapy and may require support with mechanical ventilation or extracorporeal membrane oxygenation. ${ }^{166}$ Efficacy of chronic transfusion has been shown in a randomised controlled trial in the prevention of future episodes of ACS. ${ }^{67}$

\section{Corticosteroids}

A short course of corticosteroids has been shown to reduce the need for blood transfusion and the length of hospitalisation in children with ACS. ${ }^{68}$ However, its use in vaso-occlusive pain crisis is associated with more rebound attack. ${ }^{69}$ Corticosteroids therapy, therefore, should be considered experimental in ACS.

\section{Nitric oxide}

NO may be beneficial in severe cases that are refractory to standard therapy. ${ }^{56} 7071$ There are isolated reports of significant reduction in pulmonary artery pressure, pulmonary vascular resistance, and alveolar-arterial gradient with concomitant improvement in cardiac output in patients with ACS after the inhalation of $\mathrm{NO}^{70}{ }^{71}$ 


\section{Box 4: Treatment of acute chest syndrome}

- Identify and treat all underlying precipitating factors.

- Supplemental oxygen to treat hypoxia and maintain arterial oxygen tension above $70 \mathrm{~mm} \mathrm{Hg}$.

- Optimal pain control and fluid management.

- Ongoing respiratory therapy by using incentive spirometry and chest physical therapy as necessary.

- Provide empirical antibiotic with coverage for atypical organisms.

- Bronchodilators for patients with reactive airway disease.

- Simple or exchange transfusion to reduce haemoglobin $S$ concentration and to enhance oxygen carrying capacity.

- Miscellaneous: NO inhalation, systemic steroids, mechanical ventilation, and extracorporeal membrane oxygenation.

\section{Hydroxyurea}

The incidence of ACS is significantly reduced in adult patients treated with hydroxyurea. ${ }^{72}{ }^{73}$ A double blind, placebo controlled trial of 299 adults with SCD was terminated early, because hydroxyurea reduced the frequency of ACS, hospitalisation, and need for transfusion. ${ }^{73}$ Hydroxyurea reduces sickling by increasing fetal haemoglobin level and hence decreasing the relative concentration of haemoglobin $\mathrm{S}$ in the erythrocytes. It should, therefore, be considered in patients with recurrent episodes of ACS.

\section{SICKLE CELL CHRONIC LUNG DISEASE}

The exact incidence, prevalence, natural history, and methods of diagnosis of SCCLD have not been established due to the lack of detailed epidemiological studies. It is suggested that SCCLD has a prevalence of approximately $4 \%$ in patients with SCD. ${ }^{10}{ }^{74}$ SCCLD is presumably related to recurring episodes of infarction and infection and is characterised by a decrease in radiolucency of the lungs, moderate to severe impairment of pulmonary function, and in its most severe form by evidence of pulmonary hypertension $1 .{ }^{107576}$

\section{Radiographic abnormalities}

Significant radiographic interstitial lung disease has been seen in patients with SCD. $^{1075}$ In a prospective study, $41 \%$ patients with SCD who had at least one prior episode of ACS were found to have significant multifocal interstitial lung abnormalities on thin section computed tomography scans of the chest. ${ }^{75}$ A correlation was found between the severity and extent of interstitial abnormalities on computed tomography and the number of prior episodes of ACS. ${ }^{75}$

\section{Pulmonary function abnormalities in sickle cell disease} Pulmonary function abnormalities in SCD are frequent and are characterised by airway obstruction, restrictive lung disease, abnormal diffusion capacity, and hypoxaemia. ${ }^{10} 12$ 77-79 However, a restrictive airways abnormality is typically seen in patients with SCCLD. ${ }^{10} 12$ 77-79

\section{Pulmonary hypertension \\ Prevalence}

Secondary pulmonary hypertension has become an increasingly recognised complication in patients with SCD. It is associated with impaired exercise tolerance, progressive heart failure, and a high mortality. ${ }^{760-84}$ Retrospective studies of echocardiograms of patients with SCD suggested a prevalence of pulmonary hypertension from 30\% to $56 \%{ }^{76}{ }^{82-84}$ A recent prospective study based on echocardiograms in 154 patients with SCD, however, revealed a prevalence of $34 \%$ and approximately $27 \%$ of these patients found to have severe pulmonary hypertension..$^{85}$
Box 5: Management of patients with pulmonary hypertension related to sickle cell disease

- At present there is no proven therapy for pulmonary hypertension secondary to SCD.

- Vasodilators are efficacious in primary pulmonary hypertension and should be considered in patients with pulmonary hypertension related to SCD.

- Long term oxygen therapy should be used in hypoxaemic patients.

- Chronic anticoagulation therapy should be offered to these patients unless a contraindication is present.

- Cautious use of diuretics and cardiac glycosides in patients with right heart failure.

- Hydroxyurea reduces recurrent lung injury and may be beneficial in these patients.

- Pulmonary thromboendartectomy can be performed in patients with chronic macrovascular occlusion of pulmonary arteries and pulmonary hypertension.

- Role of atrial septostomy or single or bilateral lung and heart lung transplantation in these patients is not known.

Right sided cardiac catheterisation is the gold standard test for the diagnosis of pulmonary hypertension. ${ }^{80} 81$ Haemodynamic studies of patients with cardiopulmonary symptoms by right sided heart catheterisation have also demonstrated a raised pulmonary systolic and diastolic pressure. ${ }^{80} 8185-87$ Although SCD patients with echocardiographic evidence of pulmonary hypertension may not have the symptoms of cardiac dysfunction, mortality is significantly increased in these patients compared with patients without pulmonary hypertension. ${ }^{76} 82$

\section{Pathophysiology}

Pulmonary hypertension is characterised by progressive obliteration of the pulmonary vasculature. The mechanism of pulmonary hypertension complicating SCD is unknown and likely to be multifactorial. Possible causes include: sickle cell related vasculopathy due to sequestration of sickle erythrocytes, fat embolism, or recurrent infection ${ }^{21}$; chronic hypoxic stress causing irreversible remodelling of the vasculature with smooth muscle proliferation and fibrosis ${ }^{22}{ }^{88}$; recurrent pulmonary thromboembolism ${ }^{1922}$; increased blood viscosity with consequent right ventricular volume or pressure overload ${ }^{83}$; and pulmonary scarring from repeated episodes of ACS. ${ }^{22} 8189$ Regardless of the pathophysiology of pulmonary hypertension, once it becomes established, the patients are at risk for right sided heart failure.

\section{Clinical features}

Patients tend to be asymptomatic in the early stage, though with moderate to severe pulmonary hypertension they experience chest pain, dyspnoea, and hypoxaemia at rest. With disease progression they are at risk for right heart failure and sudden death from pulmonary thromboembolism, systemic hypotension, and cardiac arrhythmia. ${ }^{80}$

\section{Management}

Limited data are available in the literature regarding management of pulmonary hypertension related to SCD. The efficacy of continuous intravenous epoprostenol (prostacyclin) and calcium channel blockers, which are effective therapy in primary pulmonary hypertension, are of unknown efficacy in pulmonary hypertension secondary to SCD. ${ }^{90}{ }^{91}$ Patients with significant parenchymal lung disease may develop considerable shunt and increased oxygen requirement while receiving epoprostenol. ${ }^{92}$ Likewise, systemic blood pressure is lower than normal in patients with SCD and it is not known whether SCD patients can tolerate vasodilators. ${ }^{93}$ Various other agents including prostaglandin analogues such as subcutaneous 
Box 6: Therapeutic mechanism of nitric oxide in sickle cell disease ${ }^{2856}$

- Inhaled NO directly acts on pulmonary vasculature and improves oxygenation by reducing $V / Q$ mismatch and pulmonary artery pressure.

- NO down-regulates the expression of endothelial adhesion molecules, thereby reducing vaso-occlusion.

- NO inhibit platelet aggregation and may prevent thrombotic complication in patients with pulmonary hypertension.

- NO may contribute to the induction of fetal haemoglobin by hydroxyurea.

- NO inhalation enhance NO delivery to the peripheral vasculature by increasing nitrosylated haemoglobin.

treprostinil, ${ }^{94}$ inhaled iloprost, ${ }^{95}$ and oral beraprost ${ }^{96}$ as well as oral bosentin, ${ }^{97}$ an endothelin receptor antagonist, have shown efficacy in both primary and secondary pulmonary hypertension in randomised controlled trials. However, the therapeutic role of these agents in pulmonary hypertension related to SCD is not known. Recent clinical and experimental data have suggested that altered metabolism of NO may play a part in the pathogenesis of pulmonary hypertension. ${ }^{56}$ Therapeutic NO inhalation may prove efficacious in patients with SCD and secondary pulmonary hypertension due to its ability to selectively dilate the pulmonary vasculature which reduces pulmonary pressure and increases oxygenation. ${ }^{5698}$ Studies are underway to determine if inhaled NO will reduce morbidity and mortality in SCD.

In addition to vasodilators, a number of adjunctive therapies can be useful in pulmonary hypertension secondary to SCD. Since pulmonary hypertension may be related to polymerisation of haemoglobin S, hydroxyurea treatment should be considered. ${ }^{72}{ }^{80}$ Furthermore, hydroxyurea decreases the incidence of ACS, multiple episodes of which may contribute to pulmonary hypertension and may also have a protective effect on the pulmonary vasculature. ${ }^{73}{ }^{80}$ Long term oxygen therapy should be considered if resting hypoxaemia is present. Results with simple or exchange transfusion are disappointing. However, the combination of exchange transfusion with long term oxygen therapy may be beneficial in pulmonary hypertension. ${ }^{80} \mathrm{~A}$ retrospective and a non-randomised prospective study suggested that anticoagulation increases survival in patients with primary pulmonary hypertension. ${ }^{80}{ }^{92}$ Chronic anticoagulation therapy is, therefore, recommended in SCD with pulmonary hypertension unless a contraindication is present. Cautious use of diuretics and cardiac glycosides may be helpful in relieving symptoms in patients with right heart failure. ${ }^{92} 99$ Pulmonary thromboendarterectomy in surgically accessible chronic thromboembolic disease with pulmonary hypertension has been performed successfully in patients with SCD and should be considered in patients with chronic macrovascular occlusion of pulmonary arteries. ${ }^{100}$ The role of atrial septostomy or single or bilateral lung and heart lung transplantation in patients with pulmonary hypertension related to SCD is not known..$^{92} 101102$

In stable patients with mild impairment (New York Heart Association (NYHA) class I or II) conventional therapy including oral anticoagulants and watchful waiting may be justified.$^{103}$ However, patients with more severe pulmonary hypertension (NYHA class III or IV) require further intervention. Therapy should be guided by the result of acute vasodilator challenge. ${ }^{103}$ In patients who show a fall in pulmonary arterial pressure and vascular resistance, calcium channel blockers remain a reasonable therapeutic option. In nonresponders and responders who are not in NYHA class I or II while being treated with calcium channel blockers, the endothelin receptor antagonist or one of the novel prostaglandins should be offered. In cases of deterioration or more advanced disease, intravenous epoprostenol should be started and atrial septostomy may be considered. Lung transplantation is less likely to be beneficial in patients with SCD due to an expected high procedure related mortality in these patients.

\section{CONCLUSION}

Pulmonary complications are common and account for a large proportion of deaths among adults with sickle cell disease. They result from the complex pathophysiology of sickle cell disease. New therapies are being developed that may prove to be beneficial in the various complications. Clinicians should be aware of acute and chronic complications of sickle cell disease, as they have emerged as major threats to the health and longevity of patients with this condition.

\section{ACKNOWLEDGEMENT}

We would like to thank Dr Joseph Mattana for reviewing the manuscript.

\section{Authors' affiliations}

A K Siddiqui, Division of Pulmonary and Critical Care Medicine, Department of Medicine, Long Island Jewish Medical Center, New Hyde Park, the Long Island Campus for the Albert Einstein College of Medicine, Bronx, New York

S Ahmed, Division of Hematology and Oncology

\section{REFERENCES}

1 Embury SH, Vichinsky EP. Sickle cell disease. In: Hoffman R, Benz JR Jr, Shattil SJ, et al, eds. Hematology: basic principles and practice. 3rd Ed. Philadelphia: Churchill Livingstone, 2000: 510-54.

2 Embury SH, Hebbel RP, Mohandas N, et al. Sickle cell anemia: basic principles and clinical practice. New York: Raven Press, 1997.

3 Bunn HF. Pathogenesis and treatment of sickle cell disease. N Engl J Med 1997;337:762-9.

4 The NHLBI working group. Respiratory diseases disproportionately affecting minorities. Chest 1995; 108:1380-92

5 Farber MD, Koshy M, Kinney TR. Cooperative study of sickle cell disease: demographic and socioeconomic characteristics of patients and families with sickle cell disease. J Chronic Dis 1985;38:495-505.

6 Platt OS, Brambilla DJ, Rosse WF, et al. Mortality in sickle cell disease. Life expectancy and risk factors for early death. N Engl J Med 1994;330: 1639-44

7 Thomas AN, Pattison C, Serjeant GR. Causes of death in sickle-cell disease in Jamaica. BM 1982;285:633-5.

8 Knight J, Murphy TM, Browning I. The lung in sickle cell disease. Pediatr Pulmonol 1999;28:205-16.

9 Haupt HM, Moore GW, Bauer TW, et al. The lung in sickle cell disease. Chest 1982;81:332-7

10 Powars D, Weidman JA, Odom-Maryon T, et al. Sickle cell chronic lung disease: prior morbidity and risk of pulmonary failure. Medicine 1988;67:66-76.

11 Koumbourlis AC, Zar HJ, Hurlet-Jensen A, et al. Prevalence and reversibility of lower airway obstruction in children with cell disease. $J$ Pediatr 2001;138: 188-92

12 Santoli F, Zerah F, Vasile N, et al. Pulmonary function in sickle cell disease with or without acute chest syndrome. Eur Respir J 1988;12:1 124-9.

13 Leong MA, Dampier C, Varlotta L, et al. Airway hyperreactivity in children with sickle cell disease. J Pediatr 1997;131:278-83.

14 Castele RJ, Strohl KP, Chester CS, et al. Oxygen saturation with sleep in patients with sickle cell disease. Arch Intern Med 1988;146:722-5.

15 Franco M, Leong M, Varlotta L, et al. Sleep hypoxemia in children with sickle cell disease. Am J Respir Crit Care Med 1996;153:A494.

16 Needleman JP, Franco ME, Varlotta L, et al. Mechanisms of noturnal oxyhemoglobin desaturation in children and adolescents with sickle cell disease Pediatr Pulmonol 1999.28:418-22.

17 Samueles MP, Stebbens VA, Davis SC, et al. Sleep related upper airway obstruction and hypoxiemia in sickle cell disease. Arch Dis Child 1992;67:925.

18 Sidman JD, Fry TL. Exacerbation of sickle cell disease by obstructive sleep apnea. Arch Otolaryngol Head Neck Surg 1988:114:916-17.

19 Maddern BR, Ohene-Frempong K, Reed HT, et al. Obstructive sleep apnea syndrome in sickle cell disease. Ann Otol Rhinol Laryngol 1989:98:174-8.

20 Hargrave DR, Wade A, Evans JPM, et al. Nocturnal oxygen saturation and painful sickle cell crises in children. Blood 2003;101:846-8.

21 Francis RB Jr, Johnson CS. Vascular occlusion in sickle cell disease: current concepts and unanswered questions. Blood 1991;77:1405-14.

22 Weil JV, Castro O, Malik AB, et al. Pathogenesis of lung disease in sickle hemoglobinopathies. Am Rev Respir Dis 1993;148:249-56.

23 Abildgaard CF, Simone JV, Schulman I. Factor-8 (antihaemophilic factor) activity in sickle-cell anaemia. Br J Haematol 1967;13:19-27. 
24 Rickles FR, O'Leary DS. Role of coagulation system in pathophysiology of sickle cell disease. Arch Intern Med 1974:133:635-41.

25 Berney SI, Ridler CD, Stephens AD, et al. Enhanced platelet reactivity and hypercoagulability in the steady state of sickle cell anaemia. $\mathrm{Am} \mathrm{J}$ Hematol 1992;40:290-4

26 Solovey A, Gui L, Key NS, et al. Tissue factor expression by endothelial cell in sickle cell anemia. J Clin Invest 1998;101:1899-904

27 Key NS, Slungaard A, Dandelet L, et al. Whole blood tissue factor procoagulant activity in patients with sickle cell disease. Blood 1998:91:4216-23.

28 Gladwin MT, Schechter AN, Shelhamer JH, et al. The acute chest syndrome in sickle cell disease: possible role of nitric oxide in its pathophysiology and treatment. Am J Respir Crit Care Med 1999; 159:1368-76.

29 Davie SC, Luce PJ, Winn AA, et al. Acute chest syndrome in sickle cell disease. Lancet 1984;i:36-8.

30 Poncz M, Kane E, Gill F. Acute chest syndrome in sickle cell disease. Etiology and clinical correlates. J Pediatr 1985;107:861-6.

31 Vichinsky EP, Styles LA, Colangelo LH, et al. Acute chest syndrome in sickle cell disease: Clinical presentation and course. The Cooperative Study of Sickle Cell Disease. Blood 1997;89:1787-92

32 Castro O, Brambilla DJ, Thorington B, et al. The acute chest syndrome in sickle cell disease: incidence and risk factors. The Cooperative Study of Sickle Cell Disease. Blood 1994:84:642-9.

33 Vichinsky EP, Neumayr LD, Earles AN, et al. Causes and outcomes of the acute chest syndrome in sickle cell disease. N Engl J Med 2000;342: 1855-65

34 Vichinsky E, Styles L. Sickle cell disease: pulmonary complications. Hematol Oncol Clin North Am 1997;10:1275-87.

35 Godeau B, Schaeffer A, Bachier D, et al. Bronchoalveolar lavage in adult sickle cell patients with acute chest syndrome: value for diagnostic assessment of fat embolism. Am J Respir Crit Care Med 1996;153:1691-6.

36 Vichinsky EP, Williams R, Das $M$, et al. Pulmonary fat embolism. A distinct cause of severe acute chest syndrome in sickle cell anemia. Blood 1994:83:3107-12.

37 Oppenheimer EH, Easterly JR. Pulmonary changes in sickle cell disease. Am Rev Respir Dis 1971;103:858-9.

38 Hassell KL, Deutsch JC, Kolhouse JF, et al. Elevated serum levels of free fatty acid in sickle cell patients with acute chest syndrome and multiorgan failure syndrome. Blood 1994;84:1633A.

39 Vichinsky EP, Lubin BH, Kuypers FA. Phospholipase A2 levels in acute chest syndrome f sickle cell disease. Blood 1996:87:2573.

40 Pond GD, Ovitt TW, Capp MP. Comparison of conventional pulmonary angiography with intravenous digital subtraction angiography for pulmonary embolic disease. Radiology 1983;147:345

41 Gelfand MJ, Daya SA, Rucknagel DL, et al. Simultaneous occurrence of rib infarction and pulmonary infiltrates in sickle cell disease patients with acute chest syndrome. J Nucl Med 1993:34:614-18.

42 Salzman SH.Does splinting from thoracic bone ischemia and infarction contribute to the acute chest syndrome in sickle cell disease? Chest 2002;122:6-9

43 Rucknagel DL, Kalinyak KA, Gelfand M. Rib infarcts and acute chest syndrome in sickle cell disease. Lancet 1991;337:831-3.

44 Bellet PS, Kalinyak KA, Shukla R, et al. Incentive spirometry to prevent acute pulmonary complications in sickle cell disease. N Engl J Med 1995; 33:699-703.

45 Haynes J, Allison RC. Pulmonary edema complications in the management of sickle cell pain crisis. Am J Med 1986;80:833-40.

46 Quinn CT, Buchanan GR. The acute chest syndrome of sickle cell disease. J Pediatr 1999;135:416-22.

47 Lubin B. Sickle cell disease and endothelium. N Engl J Med 1997;337:1584-90

48 Hebbel RP. Adhesive interactions of sickle erythrocytes with endothelium J Clin Invest 1997; 100:83-6.

49 Setty BN, Stuart M. Vascular cell adhesion molecule- 1 is involved in mediating hypoxia-induced sickle red cell adherence to endothelium: potential role in sickle cell disease. Blood 1996;88:2311-20.

50 Platt OS. Sickle cell anemia as an inflammatory disease. J Clin Invest 2000;106:337-8

51 Hofstra TC, Kalra VK, Meiselman HJ, et al. Sickle erythrocytes adhere to polymorphonuclear neutrophils and activate the neutrophil respiratory burst. Blood 1996;87:4440-7.

52 Ballas S, Larner J, Smith E, et al. Rheological predictors of the severity of painful sickle-cell crises. Blood 1988;72:1216-23.

53 Hammerman SI, Kourembanas S, Conca TJ, et al. Endothelin-1 production during the acute chest syndrome in sickle cell disease. Am J Respir Crit Care Med 1997; 156:280-5.

54 Hammerman SI, Kling ES, Hendra KP, et al. Endothelial cell nitric oxide production in acute chest syndrome. Am J Physiol 1999:H1579-92.

55 Klings ES, Christman BW, McClung J, et al. Increased F2 isoprostanes in acute chest syndrome of sickle cell disease as a marker of oxidative stress. Am J Respir Crit Care Med 2001;164:1248-52.

56 Gladwin MT, Schechter AN. Nitric oxide therapy in sickle cell disease. Semin Hematol 2001;38:333-42.

57 Stuart MJ, Setty BNY. Acute chest syndrome of sickle cell disease: a new light on an old problem. Curr Opin Hematol 2001;8:111-22.

58 Stuart MJ, Setty BN. Sickle cell acute chest syndrome: pathogensis and rationale for treatment. Blood 1999:94:1555-60.

59 Grisham J, Vichinsky E. Ketorolac versus meperidine in vaso-occlusive crisis. A study of safety and efficacy. Int J Pediatr Hematol/Oncol $1996 ; 3: 239$.
60 Needleman JP, Setty BN, Varlotta L, et al. Measurement of hemoglobin saturation by oxygen in children adolescents with sickle cell disease. Pediatr Pulmonol 1999;28:423-8.

61 Kress JP, Pohlman AS, Hall JB. Determination of hemoglobin saturation in patients with acute sickle chest syndrome. Chest 1999;115:1316-20.

62 Ahmed S, Karim A, Mattana J. Pulse oximetry for hemoglobin oxygen saturation measurement in patients with sickle cell vasoocclusive crisis. Blood 2001;98:491A

63 Maitre B Habibi A, Roudot-Thoraval F, et al. Acute chest syndrome in adults with sickle cell disease. Therapeutic approach, outcome and results of $\mathrm{BAL}$ in a monocentric series of 107 episodes. Chest 2000;1 11:1386-92.

64 Emre U, Miller ST, Gutierez M, et al. Effect of transfusion in acute chest syndrome of sickle cell disease. J Pediatr 1995;127:901-4

65 Wayne AS, Key SV, Nathan DG. Transfusion management of sickle cell disease. Blood 1993;81:1109-23.

66 Trant CA Jr, Casey JR, Hansell D, et al. Successful use of extracorporeal membrane oxygenation in the treatment of acute chest syndrome in a child with severe sickle cell anemia. ASAIO J 1996;42:236-9.

67 Miller ST, Wright E, Abboud M, et al. Impact of chronic transfusion on incidence of pain and acute chest syndrome during the stroke prevention trial (STOP) in sickle-cell anemia. J Pediatr 2001;139:785-9.

68 Bernini JC, Rogers ZR, Sandler ES, et al. Beneficial effect of intravenous dexamethasone in children with mild to moderately severe acute chest syndrome complicating sickle cell disease. Blood 1998;92:3082-9.

69 Griffin TC, Mclntire D, Buchanan GR, et al. High-dose intravenous methylprenisolone therapy for pain in children and adolescents with sickle cell disease. N Engl J Med 1994;330:733-7.

70 Altz AM, Wessel DL. Inhaled nitric oxide in sickle cell disease with acute chest syndrome. Anesthesiology 1997:87:988-90.

71 Sullivan KJ, Goodwin SR, Evangelist J, et al. Nitric oxide successfully used to treat acute chest syndrome of sickle cell disease in an young adolescent. Crit Care Med 1999;27:2563-8.

72 Marwick C. Trial halted as sickle cell treatment proves itself. JAMA 1995;273:611.

73 Charache S, Terrin ML, Moore RD, et al. Effect of hydroxyurea on the frequency of painful crisis in sickle cell anemia. N Engl J Med 1995;332: 1317-22.

74 Powars D. Sickle cell anemia and major organ failure. Hemoglobin 1990; 14:573-97

75 Aquino SL, Gamsu G, Fahy JV, et al. Chronic pulmonary disorders in sickle cell disease: findings at thin-section CT. Radiology 1994:193:807-11.

76 Sutton LL, Castro O, Cross DJ, et al. Pulmonary hypertension in sickle cell disease. Am J Cardiol 1994;74:626-8.

77 Femi-Pearce D, Gazioglu KM, Yu PN. Pulmonary function studies in sickle cell disease. J Appl Physiol 1970;28:574-7.

78 Miller GJ, Serjeant GR. An assessment of lung volumes and gas transfer in sickle anaemia. Thorax 1971;26:309-15.

79 Young RC, Rachal RE, Reindorf CA, et al. Lung function in sickle cell hemoglobinopathy patients compared with healthy subjects. J Natl Med Assoc 1988;80:509-14

80 Castro 0 . Systemic fat embolism and pulmonary hypertension in sickle cell disease. Hematol Oncol Clin North Am 1996;10:1289-303.

81 Collins FS, Orringer EP. Pulmonary hypertension and cor pulmonale in the sickle hemoglobinopathies. Am J Med 1982;73:814-21.

82 Aboubakr SE, Girgis R, Swerdlow P. Pulmonary hypertension in sickle cell disease. Am J Respir Crit Care Med 1999;160:A144.

83 Simmons BE, Santhanam V, Castaner A, et al. Sickle cell disease: two-dimensional echo and doppler ultrasonographic findings in hearts of adult patients with sickle cell anemia. Arch Intern Med 1988; 148: 1526-8.

84 Ahmed S, Siddiqui AK, Sadig A, et al. Echocardiographic abnormalities in adult patients with sickle cell disease. Blood 2002;100:453A

85 Galdwin MT, Jison ML, Sachdev V, et al. A prospective clinical study of the prevalence and etiology of secondary pulmonary hypertension in sickle cell disease. Blood 2002;100:10A.

86 Norris SL, Johnson C, Haywood LJ. Left ventricular filling pressure in sickle cell anemia. J Assoc Acad Minor Phys 1992:3:20-3.

87 Kaur K, Brown B, Lomabardo F. Prostacyclin for secondary hypertension. Ann Intern Med 2000;132:165.

88 Faller DV. Endothelial cell responses to hypoxic stress. Clin Exp Pharmacol Physiol 1999:26:74-84.

89 Rubler S, Fleischer RA. Sickle cell states and cardiomyoapthy: sudden death due to pulmonary thrombosis and infarction. Am J Cardiol 1967;19:867-72.

90 Rich S, Kaufmann E, Levy PS. The effect of high doses of calcium channel blockers on survival in primary pulmonary hypertension. N Engl J Med 1992;327:76-81.

91 Brast RJ, Rubin L, Long WA, et al. A comparison of continuous intravenous epoprostenol (prostacyclin) with conventional therapy for primary pulmonary hypertension. The Primary Pulmonary Hypertension Grimary pulmonary hypertension. The Primal J Med 1996:334:296-302.

92 Gaine S. Pulmonary hypertension. JAMA 2000;284:3160-8.

93 Johnson CS, Giorgio AJ. Arterial blood pressure in adults with sickle cell disease. Arch Intern Med 1981;141:891.

94 Simmonneau G, Brast RJ, Galie N, et al. Continuous subcutaneous infusion of treprostinil, a prostacyclin analogue in patient with pulmonary arterial hypertension: a double-blind randomized controlled trial. $\mathrm{Am} J$ Respir Crit Care Med 2002;165:800-4.

95 Olschewski H, Simonneau G, Galie N, et al. Inhaled iloprost for severe pulmonary hypertension. N Engl J Med 2002;347:322-9. 
96 Galie N, Humbert M, Vachiery JL, et al. Effect of beraprost sodium, an oral prostacyclin analogue in patients with pulmonary arterial hypersicy a hypertension: a randomized double blind placebo-cC

97 Rubin LJ, Badesch DB, Barst RJ, et al. Bosentan in patient with pulmonary arterial hypertesion: a randomized placebo controlled multicenter study. N Engl J Med 2002;346:896-903.

98 Hasuda T, Satoh T, Shimouchi A, et al. Improvement in exercise capacity with nitric oxide inhalation in patients with precapillary pulmonary hypertension. Circulation 2000;101:2066-70.

99 Rich S, Seidlitz M, Dodin E, et al. The short-term effects of digoxin in patients with right ventricular dysfunction from pulmonary hypertension Chest 1998;114:787-92.
100 Yung GL, Channick RN, Fedullo PF, et al. Successful pulmonary thromboendarterectomy in two patients with sickle cell disease. Am J Respir Crit Care Med 1998;157:1690-3.

101 Kerstein D, Levy PS, Hsu DT, et al. Blade balloon atrial septostomy improves survival in patients with severe primary pulmonary hypertension. Circulation 1995;91:2028-35.

102 Hosenpud JD, Bennett LE, Keck BM, et al. The Registry of the International Society for Heart and Lung Transplantation: fourth official report 1997. J Heart Lung Transplant 1997;16:691-712.

103 Hoeper MM, Nazzareno G, Gerald S, et al. New treatment for pulmonary arterial hypertension. Am J Respir Crit Care Med 2002:165:1209-16.

Clinical Evidence-Call for contributors

Clinical Evidence is a regularly updated evidence based journal available worldwide both as a paper version and on the internet. Clinical Evidence needs to recruit a number of new contributors. Contributors are health care professionals or epidemiologists with experience in evidence based medicine and the ability to write in a concise and structured way.

Currently, we are interested in finding contributors with an interest in the following clinical areas:

Altitude sickness; Autism; Basal cell carcinoma; Breast feeding; Burns; Carbon monoxide poisoning; Cervical cancer; Chronic renal failure; Cystic fibrosis; Ectopic pregnancy; Emphysema; Grief/bereavement; Halitosis; Hodgkins disease; Infectious mononucleosis (glandular fever); Jet lag; Kidney stones; Malignant melanoma (metastatic); Mesothelioma; Myeloma; Ovarian cyst; Pancreatitis (acute); Pancreatitis (chronic); Polycystic ovaries; Polymyalgia rheumatica; Post-partum haemorrhage; Pulmonary embolism; Recurrent miscarriage; Repetitive strain injury; Scoliosis; Seasonal affective disorder; Squint; Systemic lupus erythematosus; Testicular cancer; Uterine prolapse; Varicocele; Viral meningitis; Vitiligo

However, we are always looking for others, so do not let this list discourage you.

Being a contributor involves:

- Appraising the results of literature searches (performed by our Information Specialists) to identify high quality evidence for inclusion in the journal.

- Writing to a highly structured template (about 2000-3000 words), using evidence from selected studies, within 6-8 weeks of receiving the literature search results.

- Working with Clinical Evidence Editors to ensure that the text meets rigorous epidemiological and style standards.

- Updating the text every eight months to incorporate new evidence.

- Expanding the topic to include new questions once every 12-18 months.

If you would like to become a contributor for Clinical Evidence or require more information about what this involves please send your contact details and a copy of your CV, clearly stating the clinical area you are interested in, to Claire Folkes (cfolkes@bmigroup.com).

\section{Call for peer reviewers}

Clinical Evidence also needs to recruit a number of new peer reviewers specifically with an interest in the clinical areas stated above, and also others related to general practice. Peer reviewers are health care professionals or epidemiologists with experience in evidence based medicine. As a peer reviewer you would be asked for your views on the clinical relevance, validity and accessibility of specific topics within the journal, and their usefulness to the intended audience (international generalists and health care professionals, possibly with limited statistical knowledge). Topics are usually 2000-3000 words in length and we would ask you to review between 2-5 topics per year. The peer review process takes place throughout the year, and our turnaround time for each review is ideally 10-14 days.

If you are interested in becoming a peer reviewer for Clinical Evidence, please complete the peer review questionnaire at www.clinicalevidence.com or contact Claire Folkes (cfolkes@bmigroup.com). 